\title{
Alternate-year Pruning Recommended for Cranberry
}

Bernadine C. Strik ${ }^{1}$

Department of Horticulture, Oregon State University, Agricultural and

Life Sciences, Building 4017, Cowallis, OR 97331-7304

\section{Arthur Poole}

\section{Coos County Extension, Coos County Coquille Annex, 290 North}

Central, Coquille, OR 97423

Additional index words. Vaccinium macrocarpon, yield components, fruit color

In a study examining the short-term effects of pruning severity on cranberries, Strik and Poole (1991) reported that unpruned and lightly pruned vines had higher total plant fresh weight, more berries, higher berry yield, longer and more fruiting uprights $\left(\mathrm{U}_{\mathrm{F}}\right)$, and fewer nonfruiting uprights $\left(\mathrm{U}_{\mathrm{N}}\right)$ than moderately or heavily pruned vines. Anthocyanin content of berries, a major factor in quality, was unaffected by pruning severity the first year, but unpruned vines produced berries with less color the second year. This study examines the longer-term effect of the earlier study.

The experiment was conducted on a 30year-old 'McFarlin' cranberry bed. Details of the experiments were as reported by Strik and Poole (1991). Pruning severity (heavy, moderate, light, or no pruning) treatments were repeated on each plot in 1989 and 1990. Plots were $1.8 \times 6 \mathrm{~m}$. The cranberry bed was not pruned in 1991; thus, control plots were not pruned for 3 years. In Sept. 1991, yield component data were collected. Samples from two 3-dm areas were collected and pooled from each plot. Data were extrapolated to represent an equivalent area to facilitate comparison with Strik and Poole (1991). Data were analyzed as a randomized complete block design with six replicates.

There was no difference among treatments

Received for publication 4 May 1992. Accepted for publication 17 Aug. 1992. Oregon State Univ. Agricultural Experiment Station Technical Paper no. 9884 . We gratefully acknowledge the technical assistance of Dawna Jackson and the support of the Oregon Cranberry Growers Assn. The cost of publishing this paper was defrayed in part by the payment of page charges. Under postal regulations, this paper therefore must be hereby marked advertisement solely to indicate this fact.

Associate Professor.

${ }^{2}$ Horticultural Extension Agent. cyanin content than the unpruned or lightly pruned vines (Table 1), presumably because of more light exposure. Total anthocyanin content was less than that found by Strik and Poole (1991) because data were not collected as near to the actual commercial harvest date in this study. Although there was no significant difference in yield in 1991, lightly pruned vines tended to have higher yield than the rest (Table 1). These data, along with our previous study (1991), indicate that pruning lightly in alternate years leads to higher long-term yields. In 1990, after two consecutive years of light pruning, yield decreased 26\% (Table 1). After not pruning for 1 year, these same lightly pruned plots had an $89 \%$ increase in yield compared with 1990 (Table 1). The unpruned plots, however, had only a $14 \%$ increase in yield compared with 1990 (Table 1). Chambers (1918) also found a $10 \%$ reduction in yield the year after pruning but a $45 \%$ increase in yield the 2nd year after pruning. Cumulative yield over 3 years (1989-91) was highest for the lightly pruned and lowest for the heavily pruned plots (50 and $33 \mathrm{t} \cdot \mathrm{ha}^{-1}$, respectively). Overpruning, therefore, reduces long-term yield. Alternate-year, light pruning is recommended to maintain high yield and good fruit color in cranberry in the Pacific Northwest.

\section{Literature Cited}

Chambers, F.S. 1918. Pruning experiments. Proc. 48th Annu. Meeting Amer. Cranberry Grower's Assn., E. Wareham, Mass. p. 3-7.

Doehlert, C.A. 1955. Pruning cranberries. Proc. 85th Annu. Meeting Amer. Cranberry Grower's Assn., E. Wareham, Mass. p. 15-19.

Eck, P. 1990. The American cranberry. Rutgers Univ. Press, New Brunswick, N.J. p. 225226.

Strik, B.C. and A. Poole. 1991. Timing and severify of pruning effects on cranberry yield components and fruit anthocyanin. HortScience 26:1462-1464.

Table 1. Effect of pruning severity in 1990 on yield components of 'McFarlin' cranberry in 1991.

\begin{tabular}{|c|c|c|c|c|c|c|c|c|c|c|}
\hline \multirow{2}{*}{$\begin{array}{l}\text { Pruning } \\
\text { treatmenty }\end{array}$} & \multicolumn{3}{|c|}{ Upright no. ${ }^{2}$} & \multicolumn{3}{|c|}{$\left(\mathrm{U}_{\mathrm{F}} / \mathrm{U}_{\mathrm{T}}\right) \times 100(\%)$} & \multicolumn{3}{|c|}{ Est. yield $\left(\mathrm{t} \cdot \mathrm{ha}^{-1}\right)$} & \multirow{2}{*}{$\begin{array}{l}\text { Anthocyanir } \\
(\mathrm{mg} / 100 \mathrm{~g})\end{array}$} \\
\hline & $\mathrm{U}_{\mathrm{T}}$ & $\mathrm{U}_{\mathrm{N}}$ & $U_{F}$ & $1989^{x}$ & $1990^{x}$ & 1991 & $1989^{x}$ & $1990^{x}$ & 1991 & \\
\hline Unpruned & 681 & 512 & $170 \mathrm{ab}^{\mathrm{w}}$ & $35 a$ & $23 \mathrm{a}$ & 28 & $17.5 \mathrm{a}$ & $11.8 \mathrm{a}$ & 13.4 & 26 \\
\hline Light & 702 & 513 & $189 \mathrm{a}$ & $27 \mathrm{ab}$ & $15 \mathrm{~b}$ & 27 & $16.0 \mathrm{ab}$ & $11.8 \mathrm{a}$ & 22.3 & $23 \mathrm{~b}$ \\
\hline Moderate & 665 & 524 & $141 \mathrm{~b}$ & $19 \mathrm{bc}$ & $11 \mathrm{c}$ & 21 & $10.4 \mathrm{bc}$ & $9.4 \mathrm{ab}$ & 17.5 & $27 \mathrm{ac}$ \\
\hline Heavy & 668 & 515 & $153 \mathrm{ab}$ & $18 \mathrm{c}$ & $9 \mathrm{c}$ & 22 & $9.7 \mathrm{c}$ & $6.5 \mathrm{~b}$ & 16.9 & $31 \mathrm{c}$ \\
\hline Significance & NS & NS & * & $* *$ & $* *$ & NS & * & $* *$ & NS & $* * *$ \\
\hline
\end{tabular}

2Sample area of $930 \mathrm{~cm}^{2} ; U_{T}=$ total number of uprights; $U_{N}=$ nonfruiting uprights; $U_{F}=$ fruiting uprights.

yPlots pruned in Winter 1989-90; unpruned had not been pruned for 3 years. Light, moderate, and severe pruning as described by Strik and Poole (1991).

$\times 1989$ and 1990 data from Strik and Poole (1991).

wean separation by the Waller test, $P=0.05$.

Ns. $, \cdots, \cdots$ Nonsignificant or significant at $P=0.05,0.01$, or 0.001 , respectively. 